UDC 658.5.011.16

\title{
WAYS OF EFFICIENCY IMPROVING OF MODERN PRODUCTION
}

\author{
S. Voinova \\ Odessa National Academy of Food Technologies, Odessa, Ukraine \\ ORCID: 0000-0003-0203-0599 \\ E-mail: voinova_s@yahoo.com
}

Copyright (C 2017 by author and the journal "Automation technological and business - processes". This work is licensed under the Creative Commons Attribution International License (CC BY). http://creativecommons.org/licenses/by/4.0/

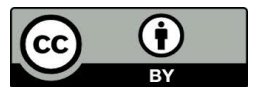

ONAFT

Open Access

Abstract: The most part of the operating technological equipment in Ukraine has spent the estimated resource of working capacity, has passed in a limiting condition, therefore works with low technological indicators of efficiency of functioning of a technical object. These indicators include three components: environmental, economic and general technical efficiency. The increase of these indicators is a complex and important problem of increasing the efficiency of functioning of the operating technological objects, control of their condition and operating mode. It can be implemented by partially updating worn-out technical facilities. The solution of this problem is characterized by considerable profitability with relatively low resource intensity. The program of work on renovation requires the development and application of means of operational controls for the components of technological efficiency of the renovated technical objects and in assessing the possible effectiveness of their application. Implementation of the similar program needs strengthening of social responsibility of technicians of all levels responsible for quality of process of functioning of the worn-out equipment.

Keywords: Production, technological process, technical object, enhancement, technological efficiency, control, expenditure, resource of working capacity.

\section{Introduction}

In Ukraine, currently operating technical objects (TO), from the moment of commissioning, are subject to the impact of the process of wear and tear. Due to this, the TO technological properties are degraded, accordingly, the level of its technological efficiency $\left(\mathrm{E}_{\mathrm{T}}\right)$ is reduced from the level of the initial (maximum) $\mathrm{E}_{0}$ to the level of the minimum permissible $\mathrm{E}_{\mathrm{min}}$. This process takes a period of time equal to the duration of the service life of the TO, designated by its manufacturer.

With a progressive approach to control of the process of TO functioning, the formation $\mathrm{E}_{\mathrm{T}}$ of this process is carried out in three stages. In their composition there are technological, design and operational stages. The first and second ones form the accumulation period, the third - the expenditure period $[1,2]$.

Let's agree, further, the concept " $\mathrm{E}_{\mathrm{T}}$ of the process of TO functioning" is presented in the abbreviation "TO $\mathrm{E}_{\mathrm{T}}$ ".

As it is known, $E_{\mathrm{T}}$ is formed by three components: ecological $\mathrm{E}_{\mathrm{l}}$, economic $\mathrm{E}_{\mathrm{n}}$ and general technical Es:

$$
E_{\mathrm{T}}=f\left(E_{1}, E_{n}, E_{s}\right) \text {. }
$$

In each specific case, for each of these indicators, there are set the minimum permissible levels $\left(E_{1}\right)_{\min },\left(E_{n}\right)_{\min },\left(E_{s}\right)_{\min }$.

From the sets of properties of each of these components, there is selected the main property (the main indicator) of $\mathrm{E}_{\mathrm{T}} \mathrm{TO}$. By this property, in the long run, there is assigned TO resource, according to ecological, economic and general technical properties.

To assign a TO resource, it is necessary to have information about the patterns of change in time (T) (that is, about the dynamics of change) of the selected three performance efficiency indicators under the effect of the TO wear process: ( $E_{1}$, $E_{n}$, $\mathrm{E}_{\mathrm{s}}$ ). These fundamentally important regularities are the subject of studying within the framework of technical gerontology [3].

Further, it is necessary to select the level of the minimum permissible value of each component $E_{\mathrm{T}}$ : $\left(\mathrm{E}_{\mathrm{l}}\right)_{\min },\left(\mathrm{E}_{\mathrm{n}}\right)_{\min }$ and $\left(\mathrm{E}_{\mathrm{s}}\right)_{\min }$.

By the function $E_{1}(T)$ and the value $\left(E_{1}\right)_{\min }$, they found the size of the TO resource $-R_{1}$. Similarly, they found the size of the TO resource $\mathrm{R}_{\mathrm{n}}$ and the size of the $\mathrm{R}_{\mathrm{s}}$ resource.

In general, the sizes of the three found resources are different. 
The received sizes of resources should be ranked according to the degree of importance in specific, specified conditions for the TO using.

It is logical as the TO resource to consider identified resource for the main of the three studied main its properties. Proceeding from the necessity to exclude the possibility of using the TO after exhausting its assigned resource (that is, the resource by the main property), it is necessary that the size of this resource exceed the size of the resources by two other, basic properties. Under this condition, TO will reach depletion of the resource by one of the other two properties and will be taken out of service. In this case, it will still have an unused residual resource on the main property. That is, the current level of the main technological property will not be lower than its accepted minimum allowable value. This is a fundamental importance result (condition).

A similar example is the case when as TO resource has been designated (assigned) resource for an environmental property. This object must be decommissioned by exhausting the resource (for example, by reliability) $\mathrm{R}_{\mathrm{s}}$. For this TO at the time of its decommissioning, the remaining resource for environmental friendliness will still be a certain period of time - a reserve.

In real production conditions, there is characteristic an irregular TO functioning mode when there occur random deviations from routine operating conditions, violation of the TO regime and conditions of its operation, failures, accidents, etc. Such extra-irregular violations of the regime negatively affect on the TO state, its properties and, as a consequence, reduce (stepwisely) the effectiveness of the process of its functioning. Moreover, the amount of damage caused by these extraregulatory impacts, by each of the components - $E_{\mathrm{l}}, \mathrm{E}_{\mathrm{n}}$ and $\mathrm{E}_{\mathrm{s}}$ - is different. In such conditions, the $\mathrm{E}_{\mathrm{T}}$ level of production is low, especially if the equipment has completed the use of the resource, that is, it has passed to the limit state. In a significant part of domestic production, including in the energy sector, such equipment constitutes the main part of the TO park.

Statement of problem

At the same time, the accumulated experience shows that the operating TO have a certain reserve to increase their level of $\mathrm{E}_{\mathrm{T}}$. It is all the more expedient to use this possibility, the lower the level of efficiency of the TO working, that is, the more they are worn out.

In the current difficult conditions, the ability to using reserves of improve the efficiency of the worn-out equipment functioning process has become acute.

It was created a complex and important problem of increasing the efficiency of the operations TO functioning, by controlling their state and mode of operation.

Solution of problem

To solve the problem, it is necessary within the limits of the visible perspective, during the replacement of worn-out equipment by new ones, in parallel to implement a program for improving the state of operating equipment, to use reserves to increase the level of its technological efficiency.

It is necessary to ensure the implementation of a program of activities aimed at studying of worn out TO, monitoring the current level of their ET, its components, finding and using a reserve, real opportunities to increase the performance indicators of these objects. In fact, it is necessary and extremely expedient to carry out a partial renewal of worn-out equipment, normalize its operation mode, improve the quality of maintenance, and improve the quality of the technological process control, carried out by automatic control systems $[4,5,6]$.

Such opportunities really exist. They are available and relatively little resource intensive. For their use, it is necessary to carry out a set of measures that are quite affordable with respect to financial costs, but require the strengthening of employee social responsibility, psychological and organizational and technical conditions at the production site, and raising the level of technological culture in all its manifestations.

In the problem of increasing the efficiency of operating worn-out equipment, it is important to quickly determine the current state of a particular operating TO, that is, the task of operative measurement of its ET level. To solve this problem, it is necessary quickly to measure the level of the components of ET, namely, El, En, and Es.

Further, having considered the technological purpose and practical conditions for using the examined TO, from the standpoint of the current regulatory provisions, it should be made a critical assessment of the established level of each of the three ET components. Special attention should be paid to the main property that determines the level of TO ET,- its residual resource.

Further, it is necessary to critically assess the current TO state, outline a set of technical measures that will allow to update TO, to use the available reserve of an affordable increase of its ET level. Here, a decent place should be allocated to the control of the production site and the updated TO in it.

In the studying of the effectiveness of the TO functioning, it is necessary to strive for the using of the balance TO ET [7].

So you can imagine the algorithm for control the program to improve the performance of worn-out equipment.

It is important to ensure this situation when adjustments made to the regulations of TO operation and maintenance, as well as in setting up the work of the staff for TO would be accessible, feasible for it and for the enterprise.

Such a solution of the problems in this direction will make it possible to use the TO most expediently in the period prior to its imminent write-off.

It should be specially noted that it is important that the reasonably developed (in terms of content and volume) updating of the operating TO is, in general, expedient, since it is accompanied by a positive effect. Its size is determined by the level of 
qualification, professional and general culture of the developers of the renewal program, the executors of the program and the operators using the updated TO.

In the implementation of the program interested enterprises - owners of obsolete equipment.

The governing bodies of all levels must initiate and support the desire to renew of worn-out equipment. Efforts by enterprises actively working to increase production efficiency should be stimulated and encouraged.

To increase the effectiveness of work on the issue in question, it is advisable to expand research in the field of technical gerontology. It is also necessary in the field of technical diagnostics to develop the technology and facilities of operational control of over all indicators of the TO ET level that available in the operational conditions. It is necessary to expand the availability of operational use in the production of modern methods and means of nondestructive testing of the properties of structural materials, the state of structural elements, the assessment of the effect of fatigue phenomena on them, the effects of vibration, hard radiation, noise of the TO mode parameters and others.

The program for updating of existing TO can be characterized by a number of parameters. Among them, the most important are two parameters: systematic, reflecting the nomenclature of works carried out at the object, and scale, reflecting the breadth of coverage of the work of the TO park.

As is known, with increasing systematic and scale of ongoing work on TO updating, the specific effectiveness of resources increases.

In the mechanism of the program, the level of systematization and the level of scale of works are interrelated synergistically. As a consequence, with the expansion of the systematic and the scale of the work carried out under the program, the specific effectiveness of the resources will increase.

This important property of the renewal of functioning TO program shows the feasibility of expanding the scope of its application in different industries and the expediency of expanding the range of work on each updated functioning TO.

It is advisable that correctly compiled and implemented program of partial renewal of worn out TO ensures a complex positive effect. It can be highly profitable in relation to the specific volume of realized resources and the specific volume of the received positive technological effect from the application of the updated TO. This effect is influenced by the nature, volume and quality of work under the upgrade program, is influenced by the maintenance of upgraded equipment.

Considerable interest is attracted by the variety of possible versions of the upgrade program. In particular, variant of a phased (multi-stage) update is interesting. Together with a partial selective update, it allows you to update flexibly and quickly small TO items for the selected character, volume and graphics.

In each department it is expedient to organize a group of specialists for highly skilled work on the organization of renewal programs in relation to the characteristic groups of technological aggregates and systems. Deepening the specialization of the activities of this group will be accompanied by an increase in the productivity of production.

The purpose of organization of this group is high-quality control of the process of increasing the technological efficiency level of the worn-out equipment operated in the area. The state importance of the tasks entrusted to such groups in production is obvious.

Conclusion

1. Nowadays a significant part of the operating equipment has fulfilled the resource of working capacity, therefore it functions with a low level of $\mathrm{E}_{\mathrm{T}}$.

2. Increasingly urgent is the problem of using the reserve in improving the efficiency of the functioning of worn out TO.

3. Such reserve is significant, and its using in most cases is feasible and technically and economically feasible.

4. For research the possibility and feasibility of a partial updating of the functioning TO, it is necessary to have information about the current level of its $E_{1}, E_{n}$ and $E_{s}$, as well as the pattern of the influence of wear on the TO $E_{T}$.

5. The considered algorithm for increasing the efficiency of the functioning of the functioning TO can be implemented at all three stages of the formation of $\mathrm{TO} \mathrm{E}_{\mathrm{T}}$.

6. The program to improve the efficiency of functioning TO on the potential value of the expected results is worthy of conceptual status.

7. The implementation of the program will be one of the productive elements of the strategy for updating fixed assets in domestic production during the transition to an innovative scenario of its development.

8. The effectiveness of the implementation of the program for the renewal of worn-out equipment is determined to a high degree by the quality of the control of the program execution process.

References

[1] S.O. Voinova Mozhlivosti upravlinnya efektivnistyu tehnichnih ob'ektiv. Trudyi 15-y Mezhdunar. n.-t. konf. «Fizicheskie i kompyuternyie tehnologii», December 2-3, 2009, Kharkiv: HNPK «FED», pp. 393 - 395, 2009.

[2] Voinova S.A. Osobennosti formirovaniya resursa tehnicheskih ob'ektov. Energetika ta elektriflkatsIya, №10, pp. 40 43, 2012.

[3] S.A. Voinova Tehnicheskaya gerontologiya. Potentsial vliyaniya na effektivnost funktsionirovaniya tehnicheskih ob'ektov. Mater. za VI Mezhdunarodna nauchna praktichna konferentsiya «Naynovite postizheniya na evropeyskata nauka-2010», June 17 - 25, 2010. Vol. 20 «Tehnologii. Fizicheska kultura i sport», Sofiya: «Byal GRAD-BG» OOD, pp. $79-84,2010$. 
[4] S.A. Voinova Obnovlenie kak instrument razvitiya proizvodstva / Izvestiya vuzov i energeticheskih ob'edineniy SNG, № 2, pp. 69-74, 2013.

[5] S.A. Voinova Upravlyat tehnologicheskoy effektivnostyu funktsionirovaniya iznoshennyih tehnicheskih ob'ektov chastichnyim obnovleniem. Materialyi Mezhdunarodnoy nauchno-prakticheskoy konferentsii «Problemyi ekologii $i$ energoeffektivnosti $v$ sovremennom stroitelstve», November 24-25, 2016, Azerbaydzhan, Baku: Azerbaydzhanskiy arhitekturno-stroitelnyiy universitet, pp. 45-50, 2016.

[6] A.P. Voinov, S.A. Voinova, O.V. Kovalenko Vyiborochnoe obnovlenie - instrument upravleniya effektivnostyu funktsionirovaniya sistem teplosnabzheniya. Zbirka tez dopovidey naukovo-praktichnoyi konferentsiyi "Problemi ta perspektivi rozvitku budivelnogo kompleksu m.Odesi”, September 22-24, 2016, Odesa: ODABA, p. 101, 2016.

[7] S.A. Voinova Assessment of the state of a technical object using the balance of its technological efficiency of operation. Otsinka stanu tehnichnogo ob'ekta z vikoristannyam balansu yogo tehnologichnoyi efektivnosti ekspluatatsiyi . Automation of technological and business-processes, Volume 9, Issue 1, pp. 14-17, 2017.

\section{Література}

[1] Воінова С.О. Можливості управління ефективністю технічних об'єктів / Труды 15-й Междунар. н.-т. конф. «Физические и компьютерные технологии», Харьков, 2-3 декабря 2009г.- Х.: ХНПК «ФЭД», 2009. - С. 393-395.

[2] Воинова С.А. Особенности формирования ресурса технических объектов / Енергетика та електрифікація, №10, 2012. - C. 40-43.

[3] Воинова С.А. Техническая геронтология. Потенциал влияния на эффективность функционирования технических объектов / Матер. за VI Международна научна практична конференция «Найновите постижения на европейската наука-2010», 17-25 юни, 2010г. Том 20 «Технологии. Физическа култура и спорт». - София: «Бял ГРАД-БГ» ООД, 2010. - С. 79-84.

[4] Воинова С.А. Обновление как инструмент развития производства/ Известия вузов и энергетических объединений СНГ, 2013, № 2. - С. 69-74.

[5] Воинова С.А. Управлять технологической эффективностью функционирования изношенных технических объектов частичным обновлением / Материалы Международной научно-практической конференции «Проблемы экологии и энергоэффективности в современном строительстве», 24-25 ноября 2016, Азербайджан, Баку: Азербайджанский архитектурно-строительный университет, 2016.- С. 45-50.

[6] Воинов А.П., Воинова С.А., Коваленко О.В. Выборочное обновление - инструмент управления эффективностью функционирования систем теплоснабжения / Збірка тез доповідей науково-практичної конференції “Проблеми та перспективи розвитку будівельного комплексу м.Одеси”, Одеса, 22-24 вересня 2016р. - Одеса: ОДАБА. - С. 101.

[7] Voinova S. Assessment of the state of a technical object using the balance of its technological efficiency of operation / Воинова С. Оцінка стану технічного об'єкта з використанням балансу його технологічної ефективності.

\section{Цитата номеру:}

\section{«Every great advance in science has issued from a new audacity of imagination»}

